\title{
Multisensory Experiences of Italian Tourists in Rural Transylvania
}

\author{
Codrina Şandru*, Florin Nechita**
}

\begin{abstract}
The concept of experiential tourism is a foundation for the valorisation of intangible cultural heritage of a rural area from south-eastern Transylvania, Romania. The experience was closely observed and analysed in order to determine how the regional tourism promotion organizations should use intangible heritage assets in order to promote this area, and also to be incorporated in the tourist offers by Romanian tour operators. Aiming to evaluate tourists' insights on their rural tourism experience, a close research was conducted among the participants at an international summer school, specially designed for the valorisation of the intangible cultural heritage. The results outline the sensorial triggers, which describe Italian tourists' experience in Fagaras Land.
\end{abstract}

Keywords: Global Tourism; Rural Tourism; Intangible Heritage; Tourist Experience; Multisensory Experience; Transylvania; Fagaras Land; Italian Tourists; Destination Marketing

\section{Experimental Tourism and Intangible Cultural Heritage}

With the dramatically change of the world's economy that changes the servicebased requirement into experience-based one (Pine \& Gilmore, 1998), peoples needs will continue to focus more on the consumption for experiences rather than products (Kim et al., 2012). As one of the main providers of consumers' experiences, the tourism industry must adapt to this new experience-based paradigm. Tourism industry should act in the way of creating memorable tourist experiences (MTEs) in order to achieve success into a highly tourism competitive market (Kim, 2014). The main properties of the experiences should be: involvement of all senses; having a unique process with intrinsic value for individuals; irreversibility; involvement of the contact with 'raw stuff', the real thing (Bulencea \& Egger, 2015). It is in the industry's interest to make an impact with great stories that can engage and excite the tourists, and get them emotionally involved in order to create memorable experiences (Lund, 2012), and the usergenerated content published online can amplify the effects of it.

\footnotetext{
* Associate Professor of Sociology and Community Development, Transilvania University of Brașov (csandru@unitbv.ro )

** Lecturer in Marketing, Advertising and Branding, Transilvania University of Brașov (florin.nechita@unitbv.ro)
} 
Culture and tourism have a strongly connected and beneficial relationship that can strengthen the attractiveness and competitiveness of places, and can create a mark in a crowded global market place. In the same time, tourism is an important source in valorizing culture and creating income which can support and strengthen cultural heritage, cultural production and creativity (Richards, 2010). As the interest moves from specific cultural attractions, such as monuments and museums, towards intangible factors in the attractiveness of places, it promotes intangible heritage values for the traveler's requirement for more fulfilling and meaningful experiences. Thus, experiential tourism becomes more important in encouraging the meeting and coming together of different cultures, their problems and potentials, especially in rural areas (Smith, 2005). The link between tourism production and tourist experience should be analyzed on five different perspectives: 1) supply perspective; 2) private and public stakeholder's coordination; 3) territorial marketing perspective; 4) landscape marketing perspective; 5) equity perspective (Dissart \& Marcouiller, 2012).

Considering the aforementioned trends, the present paper explores the concept of experiential tourism as fundamental for the valorization of the intangible cultural heritage, with a special focus on a Romanian tourist destination, Fagaras Land (םara Făgăranului in Romanian). This paper highlights the main types of experiences that can be promoted by tourism services providers and the regional and local authorities in the studied area, and can be included in tourism packages offered by regional and national tour operators. Aiming to evaluate themes and elements for an effective experiential tourism, a qualitative research was conducted among the participants to a unique thought-out experience in Fagaras Land. Because the focus of the designed and researched tourism experience was the valorization of the local intangible cultural heritage, consequently, the main objectives of this paper are to identify the sensorial triggers that best describes Italian tourists' experience in Fagaras Land.

\section{Study Background and Literature Review}

\subsection{Rural Tourism and Intangible Cultural Heritage}

The image of the rural is symbolized and idealized by tourism in various forms (Edensor, 2007), the cultural discourse that creates a mythical and idyllic countryside (Figueiredo \& Raschi,2012) and rural representations of destination images are interesting subjects to examine from a theoretical lens, and offer practical and constructive support to rural tourism (Greaves \& Skinner, 2010). A review of destination image research for specific contexts shows that destination images of rural destinations haven't appeared very often in the tourism literature (Royo-Vela, 2009). Heritage is significantly instrumental in the existential and operational sphere of tourism and could play an essential role in branding and marketing of destinations (Kuutma, 2011).

The last decades have seen a strong increase in the recognition of the value of tangible and intangible cultural heritage and the explanation is the rapid socioeconomic transformation of societies and communities and the perceived loss of genuine cultural and natural environment (Gesser et al., 2014). Although rural 
tourism is largely domestic, and positioned as a small-scale activity and an alternative to mass tourism, rural destinations are becoming increasingly popular, and the online marketing and promotion of rural destinations should be developed (Zhou, 2014).

Intangible cultural heritage is defined in the UNESCO Convention for the Safeguarding of Intangible Cultural Heritage (2003) as the practices, representations, expressions, knowledge, skills - as well as the instruments, objects, artifacts and cultural spaces associated therewith - that communities, groups and, in some cases, individuals, recognize as part of their cultural heritage. Intangible cultural heritage is transmitted from generation to generation and is constantly recreated by groups in response to their environment, their interactions with nature and their history, providing them with a sense of identity and continuity and it is manifested, inter alia, in the following domains (World Tourism Organization, 2012): handcrafts and visual arts that demonstrate traditional craftsmanship; gastronomy and culinary practices; social practices, rituals and festive events; music and the performing arts; oral traditions and expressions, including language as a vehicle of intangible cultural heritage. UNESCO Convention (2003) stated that governments, with the participation of the local people, should ensure that activities from these domains are strengthened and promoted.

Through social interaction with residents from the destination, travelers increase their understanding of the local people (who are frequently culturally different) and they may play a role as 'cultural brokers' between the newcomer and the community culture (Kim, 2014). Rural areas are increasingly represented as idyllic places in which foreigners and inhabitants have an opportunity to interact and to create a number of shared and integrated experiences based on the local traditions and resources (Halfacree, 2014). These assets may be incorporated in the creation process of tourism experiences, aimed at enhancing the quality of the tourist experience, enriching the sense of local identity and pride as well as the preservation of traditional economic activities (Carvalho et al., 2014). Tourism experience is a construct of academic study that was operationalized in many academic articles (Ritchie et al., 2011).

\subsection{The Multisensory Tourism Experiences}

Experience is a new and exciting concept in marketing, academia and practice. According to Lindstrom and Kotler (2005) our understanding of the world, for the most part, is experienced through multiple senses and customers are attracted toward brands based on sensory experience.

Tourism destinations and tourism services providers should design and deliver experiences to their customers in order to shape a differentiated image, enhance their brand equity, and consolidate an advantageous position (Andrades \& Dimanche, 2014). Tourism experiences illustrate the importance of having multiple senses involved in order to maximize the impact and future recall of these experiences. Multi-sensory information regarding tourist experiences seems to be important in destination marketing and management (Agapito et al., 2013) in order to create the brand destination sensory signature (Ditoiu \& Caruntu, 2014). As tourism moves increasingly towards adopting an experience economy, the new 
demand for unique and memorable experiences requires the development of a distinct value-added provision for products and services that have already achieved a consistent, high level of functional quality (Oh et al., 2007). Tourists want to be involved, to interact with the community in order to learn and appreciate the destination on more than a superficial level (Brondoni, 2016). Tourist experiences are essentially 'stories' about events, places and people (McCabe \& Foster, 2006), and a story 'transforms an otherwise indifferent space into attractive tourist destinations' (Chronis, 2012).

An experiential definition of cultural tourism appears the most useful when studying the relationship between tourism and intangible cultural heritage. This definition holds that tourists typically seek some form of cultural experience and that this desire is central to their choice of tourism products (World Tourism Organization, 2012). Pine and Gilmore (1998) defined consumer experiences in terms of an organization using 'services as the stage and goods as props, to engage individual customers in a way that creates a memorable event' (p. 98). Following the Pine and Gilmore (1999) recommendations, tourism companies and destinations should design and provide experience instead of delivering tourism products.

In the tourism literature, experiencing local culture has been considered an important motivational factor for traveling (e.g. Funk \& Bruun, 2007; Sharpley \& Sundaram, 2005). An authentic tourism experience will generate stories, and storytelling (the use of narratives) has become increasingly important in the experience industry because there is no better way to engage people than through stories speaking about human needs and making their lives meaningful (Mossberg, 2008). The role of narratives is fundamental in the evaluation of the tourist experience (Servidio \& Ruffolo, 2016). The success of a narrative presentation in tourism destinations depends on the tourist's involvement, willingness, and ability to actively participate in the storytelling experience (Chronis, 2012).

\subsection{Brasov Leo AdCamp - Advertising and Heritage Interpretation Summer School}

In August 2014, a 2-weeks project led by Transilvania University of Brașov and sponsored by the Brașov County Council, has brought together students, young graduates and professors from five faculties of Transilvania University of Brasov, another four Romanian universities and five foreign universities: Meisei University Tokyo, Universita Politecnica delle Marche, Universita di Macerata, University of Zadar and Salzburg University of Applied Science. The first edition of the Leo AdCamp Advertising and Heritage Interpretation Summer School (LAC-AHISS) is the name of the project which involved 40 students, graduates, advertising specialists and teaching staff from 6 countries (Romania, Italy, Japan, Austria, Croatia and The Netherlands). The advertising professionals from Leo Burnett Bucharest joined the team in a different phase of the project, in order to teach the students subjects related to marketing communication, such as advertising, public relations, art design or digital communication (Nechita et al., 2014). The participants were divided into five working groups with members from different backgrounds. Each team was assigned a specific marketing communication task (promoting of local museums from the city of Brasov, the Saxon fortified churches from the area, the Piatra Craiului Mountains National Park, and First Romanian 
School Museum, or valorizing intangible heritage of the Fagaras Land to potential tourists) to be presented at the end of 2-week project. To achieve these goals, the organizer provided field trips for all the members of the group and facilitated meetings with local experts and local community members, assisted by proffesors and advertising proffesionals from Leo Burnett Bucharest, the Romanian subsidiary of the well-known global advertising agency.

For the project part of valorizing intangible heritage of the Fagaras Land, the organizers prepared a two days tourism experience, tailor-made for these participants including: rural accommodation, local food beverage tastings, outdoor activities, and participation in traditional rituals, local artisans and museum visits.

\subsection{Fagaras Land (Țara Făgărașului)}

Fagaras Land is located in the center of Romania, in the southeastern part of the historic region of Transylvania. This area represents one of the geographical mental spaces, one of the 'lands' in Romania, which takes part in the process of conserving the local ethnographical values (Cimpoeş, 2013). Fagaras County is well known in Romanian ethnographic area through an unique material and immaterial folkloric heritage. Traditional costumes and customs, like those for winter holidays, are among most beautiful in Romania. In many rural communities these traditions, such as traditional music, dance, handicrafts and traditional agriculture are still well preserved (םandru, 2009). Dragus and at Mandra, the two villages chosen to be visited during Leo AdCAmp project, are representative for the Fagaras Land as some of the best keepers of many traditions. Dragus village, situated in the east side of Fagaras Land, is known also because of the biggest rural sociological research campaign in 1929, based on the social monograph method, coordinated by the Romanian sociologist Dimitrie Gusti.

\section{Methodology}

The 2-days intangible cultural heritage experience took place in Fagaras Land, a regional tourism destination situated in the Southern part of Transylvania, in central Romania at the end of August 2014. Participants were accommodated in two rural areas with rich and distinct intangible heritage resources, which insufficiently valorized in different tourism packages offered by tour operators: Drăguş and Mândra villages. For the purpose of this study 6 from 7 Italian students participating at LAC-AHISS were interviewed. The main demographic characteristics of the respondents: 1. Gender (two men and four women); 2. Education (all of them was students); 3. Age (22 - 25 y.o.). According to the options of the respondents, interviews were conducted in English, Romanian or Italian, but afterwards, they were all translated in English and analyzed with the Nvivo10 software.

A post-experience semi-structured interview was conducted in order to reveal participants' experience as tourists in a rural destination. In the first section of the interview guide, a narrative interview technique was used to collect relevant data about subjects' experience in Fagaras Land. The second section of the interview was built around 6 questions using associations techniques and the last question 
was focused on finding key words that best describe participants' experience in the area which can be used for promotional purposes of the destination, as well on a set of questions directed to reveal the most memorable images linked to the place visited. Three questions were constructed in order to identify three sensory experience dimensions: sight, smell and hear. The other two dimensions of their sensory experience in Fagaras Land, taste and touch, were identified from theirs stories, mentioned in the first part of the interview.

The process of content analysis has two approaches: it may be used in an inductive or deductive way (Elo \& Kyngäs, 2007). In inductive content analysis, categories derive from the data. This process includes open coding, creating categories and abstraction. The data collected was analyzed using the semistructured interviews with open, axial and selective coding techniques (Scârneci, 2007). Using the decoding, there were discovered the main themes which were present in the discussions with the interviewed respondents. Content analysis attempts to reach a better understanding of which products are enhanced and to compare with the regional tourism strategy. Studies that employ qualitative methods in tourism research and assessing destination image are rare (Govers et al., 2007). The implication of qualitative methods emerged from the principal approach of this research to obtain in-depth understanding of how travellers perceive, interpret and communicate the social reality of the destination visited (Oliveira \& Panyik, 2015). People narrate or display their experiences online environment, and after seen by other people, thus providing mediated experiences to other users. Major part of user generated content displays tourist's experiences, which present feelings and judgments about a certain tourism topic and might have an impact, being it positive or negative, onto how the destination is perceived by others ( $\mathrm{Hu}$ et al., 2014). For this reason, the data obtained from the interviews was compared with the postings on the social media (Facebook and Instagram) by Italian participants at this part of summer school. The small number of interviews ( 6 out of 7 Italian participants) hasn't been compensated by a substantiate user generated content. A total of 16 photograph and the related comments on their Facebook and Instagram walls was found during the research in January 2016. In the case of greater sample of tourists posting photos regarding theirs tourism experience, the research method of evaluating of senses involved could be done based only on photographs. Many authors evaluate destinations image perception, expectation experience, motivations or attitudes toward destination (Stepchenkova \& Zhan, 2013; Stepcenkova et al., 2014; Pan et al., 2014; Kim \& Stepchenkova, 2015).

\section{Results}

Collected data includes the key elements needed for the creation of memorable 5senses experiences, which can be further on valorized by both tour operators and local authorities. In order to find out how the Italian participants perceived Fagaras Land, we analyzed the narrative material, which describes their experience in this region and we selected those parts which represented a description of the places they have visited and the experiences they have lived. Using the open and axial coding, we found the main themes of the description and grouped them into categories which were relevant for the present study. These results are presented in 
a hierarchical format in Table 1, starting from the category which was the most mentioned to the category which was the least mentioned.

Table1: Key themes associated with Fagaras Land

\begin{tabular}{|c|c|}
\hline Category & $\begin{array}{c}\text { Number of related } \\
\text { statements }\end{array}$ \\
\hline A place with valuable traditions & 4 \\
\hline A place of spiritual values & 4 \\
\hline A place with special people & 2 \\
\hline A place different from urban areas & 2 \\
\hline A place with beautiful nature and picturesque villages & 2 \\
\hline Very good food & 1 \\
\hline
\end{tabular}

In a previous research, other three themes appeared in the analyzed stories about Fagaras Land of another 12 Romanian, Austrian and Japanese participants in two days rural experience: a place with a unique identity; a place that reminds me of my childhood and my grandparents; going back in time (Nechita et al., 2015).

The Italian tourists experience was interpreted in the frame of the personal experience for every five senses involved: sight, smell, touch, taste and hear. The results presented for every sense involved is presented in Tables 2-6. In the first column is the word associated with the experience and in the second one the explanations given by the participants.

\section{Sight}

In order to better understand the visual observation that the Italian tourists had in Fagaras Land, the participants were asked to associate their experience with a color, an animal and a plant, and to explain the reason why they made the specific choice. The purpose of asking respondents to make associations was to stimulate them to expand their story about their experience. The associations with colors, animals or plants was considered that appealed with the visual sense involvement during their experience, and for this reason some of their responses was coded in the 'sight category'.

Table 2: Associations made by Italian Participants describing theirs Visual Experience

\begin{tabular}{|c|l|}
\hline Green & $\begin{array}{l}\text { "Green - the color of the landscape surrounding us all the time" } \\
\text { "Green because Tara Fagarasului is surrounded by mountain fields and in } \\
\text { general by nature" } \\
\text { "Green - the color that predominates in the pastoral scenery" } \\
\text { "Green, for all the territory that reminds us of" } \\
\text { "White, the non-color serving as a base on which one can paint all the } \\
\text { other colors and let them shine" }\end{array}$ \\
\hline Gold & $\begin{array}{l}\text { "Gold, because it reminds the warm welcoming we've received. And also, } \\
\text { it's a color that represents something precious and Tara Fagarasului has a } \\
\text { lot of things that have to be saved and preserved for their beauty. And last, } \\
\text { it reminds the gold of the churches and holy places". }\end{array}$ \\
\hline
\end{tabular}




\begin{tabular}{|c|c|}
\hline Cow & $\begin{array}{l}\text { "A cow, because cows are calm, peaceful and fertile with milk" } \\
\text { "A cow surely, even for the "ciurda" that we have seen at 8p.m." }\end{array}$ \\
\hline Dragonfly & $\begin{array}{l}\text { "Dragonfly because Tara Fagarasului is delicate and fragile as this } \\
\text { animal" }\end{array}$ \\
\hline Horse & $\begin{array}{l}\text { "Horse: proud and majestic, incredible beauty that you can not help to } \\
\text { admire" }\end{array}$ \\
\hline Elephant & "It's an elephant, with all it's furrows narrates old stories" \\
\hline Dove & "A dove, because it represents spirituality and peace" \\
\hline Daisy & $\begin{array}{l}\text { "The daisy, because it's a pure flower like this place, where everything has } \\
\text { a begin" }\end{array}$ \\
\hline Grape vine & $\begin{array}{l}\text { "A grape vine, because I've only see one in Mandra, where we ate for } \\
\text { dinner. It also reminds the good hospitality we received, good company and } \\
\text { shared happiness" }\end{array}$ \\
\hline Leaves & $\begin{array}{l}\text { "Leaves, no matter which plant they belong to. they were all around us, you } \\
\text { could not but feel overwhelmed and protected" }\end{array}$ \\
\hline $\begin{array}{l}\text { A field of } \\
\text { corn }\end{array}$ & "The experience in the corn field that because a labyrinth was amazing" \\
\hline Edelweiss & $\begin{array}{l}\text { "Edelweiss flower, as rare and scarce as the beauty and hospitality of the } \\
\text { villagers" }\end{array}$ \\
\hline & "A plant of blackberries, because we found them near the local church" \\
\hline
\end{tabular}

As colors representative for the Fagaras Land, the respondents mentioned green, white and gold. The animals that the Italian tourists associated with Fagaras Land were cow, dragonfly, horse, dove and elephant. The plants associated with the apprehension of the visual experience in Fagaras Land are the following: daisy, grape vine, leaves, corn, edelweiss and blackberries.

\section{Smell}

For evaluating the olfactory experience of the participants, the question was direct: "what is the smell that you associate mostly with your 2 days experience in Fagaras Land?"

Table 3: Associations made by Italian Participants describing theirs Olfactory Experience

\begin{tabular}{|c|l|}
\hline Bread & $\begin{array}{l}\text { "The smell of the fresh beaked bread, because it reminds me about the } \\
\text { everyday life, traditions and peace. Even if I didn't actually smell it, I think } \\
\text { it's the most representative, also because bread has been one of the most } \\
\text { present elements of these two days". } \\
\text { "The smell of bread because of the traditional welcoming bread we tasted } \\
\text { in Mandra". } \\
\text { "The bread one because it announces a new arrival". } \\
\text { "The smell of food typical, unique and enveloping" }\end{array}$ \\
\hline $\begin{array}{c}\text { Nature } \\
\text { (plants, } \\
\text { tree) }\end{array}$ & $\begin{array}{l}\text { "The scent of plants and trees that dominate the environment" } \\
\text { "The smell of nature: you cannot define it by a single one, but you can go }\end{array}$ \\
\hline
\end{tabular}


There are two main types of smell indicated by participants as representative for their experience: the smell of bread (with a reference to the traditional food in general) and the smell of nature.

\section{Hearing}

For evaluating the way of involvement of the hearing sense in their experience, the interview contain a direct question about the sound that respondents most associated with Fagaras Land.

Table 4: Description of the Sounds associated by Italian Participants with their Experience in Fagaras Land

\begin{tabular}{|c|c|}
\hline $\begin{array}{l}\text { Traditional } \\
\quad \text { songs }\end{array}$ & $\begin{array}{l}\text { The popular song with which they welcomed the inhabitants of the village, } \\
\text { typical and unique. } \\
\text { The sounds that makes me remember Fagaras Land is the sound of the } \\
\text { traditional songs we listened in the two villages. } \\
\text { The songs sung by the old ladies and the children, because they belong } \\
\text { only to this place (I mean, I've listened to them only there) and they're } \\
\text { very emotional). } \\
\text { The squeakiness of the „welcome song” in Dragus, because it can enter } \\
\text { into your ears and wind:. }\end{array}$ \\
\hline Silence & $\begin{array}{l}\text { The sound of silence because of the full immersion in nature; the singing } \\
\text { voices (choir) for the joy they provided. }\end{array}$ \\
\hline Cow bells & $\begin{array}{l}\text { The sound of the bells of the cows, because the ciurda has been an } \\
\text { important part of the trip to Fagaras Land, in my opinion. }\end{array}$ \\
\hline
\end{tabular}

Participants indicated three categories of sounds associated with the Fagaras Land: the traditional songs they had listened in the two visited villages, the sound of silence and the sound of the cow's bells in the evening (it's about the "ciurda" herd of cows and buffalos returning home from the grazing on the villages streets in the evening).

\section{Taste}

It was identified three words that best describe the tasting experience: bread, palinka (a traditional fruit schnapps) and sarmale (the traditional stuffed cabbage).

Table 5: Description Tastes associated with Italian Participants Experience

\begin{tabular}{|c|c|}
\hline Bread & $\begin{array}{l}\text { the traditional welcoming bread we tasted in Mandra village } \\
\text { the bread one because it announces a new arrival } \\
\text { the bread that was given to us made me feel so loved }\end{array}$ \\
\hline Palinka & $\begin{array}{l}\text { long party with "florinka" (an invented word given by participants to } \\
\text { palinka, a } 50 \text { degrees alcohol fruit schnapps the participants, derived from } \\
\text { the first name of the project coordinator or "palinka produced by the } \\
\text { Florin's aunt") } \\
\text { inevitable palinka }\end{array}$ \\
\hline "Sarmale" & Sarmale for dinner...delicious! \\
\hline
\end{tabular}


The almost no postings on online social networks (only 1 photo out of 16) directed to the expected conclusion that for future Italian tourists in Fagaras Land in order to get a full positive taste experience more things have to be done.

\section{Touch}

There was a direct question about how theirs tactile experience was involved, but the results listed in the Table 6 was extracted from the main story about theirs 2days experience in the Fagaras Land.

Table 6: Description of Touch/Haptic Experience

\begin{tabular}{|c|l|}
\hline $\begin{array}{c}\text { Hand-made } \\
\text { objects }\end{array}$ & $\begin{array}{l}\text { in Mandra village we visited a house full of children, who were } \\
\text { dedicating their freshness to all kind of artistic manual works: paiting, } \\
\text { weaving, sewing } \\
\text { in Mandra, each of us has been able to test themselves with paintings on } \\
\text { glass and production of custom pins } \\
\text { created with my hands my own souvenir of this village }\end{array}$ \\
\hline Sarmale & $\begin{array}{l}\text { I sew and also rolled sarmale for dinner } \\
\text { In Mandra [...] typical food preparation }\end{array}$ \\
\hline $\begin{array}{c}\text { Traditional } \\
\text { clothes }\end{array}$ & seeing how traditional clothes and textures are made \\
\hline
\end{tabular}

There are three categories of objects that participants nominated as touching experiences: hand-made objects, "sarmale" and traditional clothes. The touch sense was strongly involved due to the three distinctive moments: 1 . visiting a traditional weaver; 2. visiting an artisan of traditional sheepskin jackets - Mr. Sofonea being on the UNESCO list of human living treasure; 3. five different manual workshops in Mandra village.

\section{Discussion, Limitations and Future Research Directions}

To provide unique experiences, tourism managers must first identify and highlight the most significant aspects of the destination's culture, history, and local way of life that makes it prominent from the rest of the tourism world (Kim, 2014). Rural tourism experience involves accompanying guests during passive activities and active participation in activities related to agriculture, handicrafts, and cultural performance (Loureiro, 2014). MTEs are often associated with seven experiential themes: (1) local people, life and culture (2) personally significant experiences (3) shared experiences (4) perceived novelty (5) perceived serendipity (6) professional guides and tour operator services and (7) affective emotions associated with memorable experiences (Chandralal \& Valenzuela, 2013; Chandralal et al., 2014). According to Volo (2009), destinations should (a) create, offer and communicate 'anticipated experiences' that individuals would classify as among those they would seek; (b) help the tourists to 'categorize experiences offerings' in easy marketdefined ways; and (c) to suggest ways to 'reinterpret the tourists experiences' by post-intervention of the tourist mind.

Research on visitor`s naturally-occurring storytelling can provide for tourism strategists information about 'exciting incidents' (McKee, 2003) representing 
unique associations and emotional highpoints that visitors are likely to retrieve and report automatically when discussing these destinations. Such storytelling reports provide creative clues for positioning a destination uniquely and meaningfully in the minds of potential future visitors. The suggestion given by Campos et al. (2016) about adopting a mix of entertainment and learning dimensions in a socially rich environment in order to enhance the experience by focusing attention toward a better knowledge acquisition and emotion elicitation have to be considered. The 'fun' dimension is not significantly revealed from the interview, though there are photos of the Italian participants that could be coded in this category. Jiang et al. (2015) pointed out that tourism authorities and destination marketers have to identify destination attributes that are most valuable in creating and enhancing fun and customer orientation experiences.

By developing their use of information technology, rural destinations have the potential to promote tourism through various online platforms (Zhou, 2014). Easy access to internet will enhance the opportunities for tourists to share their experiences on social networking sites because, at least the category of the novelty seeking travelers do not intend to re-visit the same destination despite having memorable experiences, but having intention to recommend MTEs to others (Chandralal \& Valenzuela, 2013).

The research's outcome indicates that a five-senses visitor's experience could be designed by both physical and virtual environments, thus influencing the perception of the overall tourist's experience and the individual's decision-making process. This understanding is in line with previous studies, which contours the role of rural environment in conceptualizing appealing tourist experiences by stimulating a variety of senses (Kastenholz et al., 2012), as well as the role of all the bodily senses in understanding global tourist experiences, highlighting the holistic approach to sensescapes (Urry, 2002), or adding to landscapes other kinds of scapes, such as soundscapes, tastescapes, haptiscapes and smellscapes (Agapito et al., 2013).

Designing a creative experience imply a direct interaction between tourists and the locals (Richards \& Wilson, 2006). As local population's "visitor-friendliness" is important for the tourism industry, participants interaction with local community members from Fagaras Land could enhance their intangible cultural heritage experience in this area. From the 16 photos posted on their facebook walls by two Italian participants, 10 photos depicted local people. For example, an Italian female participant used visual elements to describe her experience in Fagaras Land on her Facebook posts, using the following comment: "See people in the eyes, watch their hands".

These results have a series of practical implications for the organizations responsible for tourism development, local authorities and tour operators. The most relevant words resulted from the qualitative research and associations will help them in their attempt to develop a brand for this tourist destination. The key word most mentioned by all participants relates to tradition giving the fact that the area has a rich intangible heritage (Nechita et al., 2015). Such tourism products should include: discovery of local traditions, accommodation in peaceful areas, experiencing local hospitality, nature-based activities and interaction with local community members. In addition, the themes and key words that may be used by tour operators when promoting newly created experiences in Fagaras Land on their 
websites or in their brochures should stress these specific characteristics of the area. Local authorities play an important role in developing policies to promote and shape the development of tourism in their areas (Ispas et al., 2015). Thus, local authorities from Fagaras Land should focus on developing projects aimed at conserving and promoting the destination's intangible heritage and enhancing meaningful interactions between visitors and local communities. A competitive advantage should be constructed in relation to other regions with the reinforcements of the unique elements of the region's identity (Kavoura \& Bitsani, 2013).

Considering the implications of this research in providing key directions in order to create meaningful tourism experiences and destination branding positioning and targeting Italian and other foreign tourists, the conclusions of the present study provides relevant stakeholders with useful information. According to the interviewed subjects, a tourism experience in Fagaras Land should include all activities identified from interview or reflected in social media postings: authentic traditional music performed by the local choir, religious traditions, local food and beverage, tasting, corn maze activities, horse-drawn cart rides, traditional handicraft activities, local museums and livestock daily rituals.

As theming is a powerful tool through which an experience can be strengthened, for tourism related contexts it is preferred to select a region-specific theme, unique and personalized, because it's uniqueness represents a real competitive advantage. Otherwise, the theme can be very easily copied and used in other tourist destinations (Bulencea \& Egger, 2015). The studied destination, Fagaras Land, was perceived as a place with spirituality and peace, with beauty and hospitality of villagers and having a lot of things that have to be saved and mantained because of their beauty (intangible heritage). Ofering thematic routes focused on traditional architecture/artisans may enhance the attractivity of rural areas and provide a quality visiting experience to different market segments (Candrea, 2008). Moreover, such an approach may improve the positioning of the destination on the tourism market and outline its competitive advantage in comparison with other similar tourist destinations (Candrea, 2010). In this sense, thematic interpretation of local cultural heritage may prove to be a useful tool in creating a unique competitive advantage of the destination (Candrea, 2007). Several interpretation techniques may be used (Candrea and Nechita, 2015): personal interpretation (e.g. local guides, tourist information centers), non-personal interpretation (e.g. panels, brochures, leaflets), art interpretation (e.g. painting, sculpture, dramatic art) and multimedia inetrpretation (e.g. audio guides, 3D video mapping, QR codes).

Any branding programs should be carrefully analyzed before the implementation because frequent changes will contradict The Law of Consistency as was stated by Ries and Ries (2001): a brand is not built overnight. For creating a rural destination brand, rural communities need to identify and evaluate existing capacities to develop their tourism offer, and collaboration, partnership and all local stakeholders can contribute in achieving this (Haven-Tang \& Sedgley, 2014). Local artisans, people doing traditional agriculture and ancient cultural traditions that are still preserved in the villages of the Fagaras Land could add the most valuable input in creating a destination brand of the region.

The researches result contours that the most frequent descriptions contains subjective elements, mostly related to the appreciation of traditions and intangible heritage, which touched the soul of the visitors and generated different experiences 
from the urban life, in the company of people who preserved the unique values and identity of these places. As stated by Lugosi and Walls (2013), the different stakeholders and the (in)compatibility of their perspectives will shape destination experience research in the future.

DMOs (Destination Marketing Organisations) should consider the delivery of memorable experiences as essential to competitiveness and sustainability (Ritchie and Crouch, 2003; Tung and Ritchie, 2011). From the perspective of sustainability performance of the tourism sector, the experience of the Italian participants at LAC-AHISS, including two days in Mandra and Dragus villages from Fagaras Land, indicate that this destination could have a good score on some competitive indicators of the tourist destination as indicated by Franzoni (2015) such as \% of tourists who have a positive image of the destination, $\%$ of tourists who would recommend the destination to their peers and $\%$ of tourists attracted to destination because of unique features. The type of tourism that could be developed in this region in order to valorize the intangible cultural heritage in a sustainable way should valorize the experience from other industries influenced by the new digital culture, The Open Long Tail Model (Rieple and Pisaro, 2015). In order to promote and further enhance experience of the visitors, the introduction of personal technology such as smartphones and weareable devices should be taken into consideration (Piccoli et al., 2017).

Despite presenting useful information for the development of multisensory experiences in the studied destination, the present paper has two main limits. Although it provides interesting information for the creation of new visitor experiences and destination branding positioning, the present study has a series of limitations. First, due the qualitative research approach, it is difficult to generalize the collected data to the population of visitors in Fagaras Land. The lack of sufficient data from user generated content from tourists visiting the researched area, the main results was generated by the interpretation of only six interviews and facebook posts of just two Italian participants. In the case of destinations with substantial amount of user generated content, there are methodologies for extracting knowledge from large amount of UGC data such those proposed by Marine-Roig and Clave (2016). Future studies should use quantitative and qualitative research methods, such as surveys, focus groups or in-depth interviews, applied to a representative sample selected from the visitors population. Future research should focus on experiments and observation methods, in order to capture visitors' evaluation of multisensory experiences in Fagaras Land.

The second limitation is related to the fact that the interviewed subjects were participants at an international summer school and they did not pay for the experiences they benefited from, as tourists does.

Acknowledgements: This work used data collected during the project Leo AdCamp Advertising and Heritage Interpretation Summer School funded by the County Council of Brasov (contract 3415/25.04.2014).

\section{Bibliography}

Agapito, D., Mendes, J., \& Valle, P. (2013). Exploring the conceptualization of the sensory dimension of tourist experiences. Journal of Destination Marketing \& Management, 2(2), 62-73. 
http://dx.doi.org/10.1016/j.jdmm.2013.03.001

Andrades, L., \& Dimanche, F. (2014). Co-creation of experience value: A tourist behavior approach. In N. Prebensen, J. Chen, \& M. Uysal (Eds.), Creating experience value in tourism (pp. 95-112). London: CABI.

http://dx.doi.org/10.1079/9781780643489.0095

Brent Ritchie, J. R., Wing Sun Tung, V., \& JB Ritchie, R. (2011). Tourism experience management research: Emergence, evolution and future directions. International Journal of Contemporary Hospitality Management, 23(4), 419-438.

http://dx.doi.org/10.1108/09596111111129968

Brondoni, S. M. (2016). Global Tourism Management. Mass, Experience and Sensations Tourism, Symphonya. Emerging Issues in Management (symphonya.unimib.it), 1, 7-24.

http://dx.doi.org/10.4468/2016.1.02brondoni

Bulencea, P., \& Egger, R. (2015). Gamification in tourism. Designing memorable experiences. Norderstedt: BoD - Books on Demand.

Campos, A. C., Mendes, J., do Valle, P. O., \& Scott, N. (2016). Co-creation experiences: attention and memorability. Journal of Travel \& Tourism Marketing, 1-28.

http://dx.doi.org/10.1080/10548408.2015.1118424

Candrea, A.N., Nechita, F. (2015). The interpretation and promotion of cultural heritage in museums (in Romanian). Transilvania University Press.

Candrea, A.N. (2010). Marketing policies and strategies for the development of ecotourism in Romania (in Romanian). Transilvania University Press.

Candrea, A.N. (2008). The quality of ecotourism destinations (in Romanian). Transilvania University Press.

Candrea A.N. (2007). Marketing strategies for a sustainable tourism development. Bulletin of Transilvania University of Braşov, 14 (49), 343-346.

Carvalho, M.S., \& Lima, J., \& Kastenholz, E. (2014). Criatividade Cultural - que oportunidade para destinos rurais?. PASOS. Revista de Turismo y Patrimonio Cultural, 12(3), 635-648.

Chandralal, L., \& Valenzuela, F. R. (2013). Exploring memorable tourism experiences: Antecedents and behavioural outcomes. Journal of Economics, Business and Management, 1(2), 177-181.

http://dx.doi.org/10.7763/JOEBM.2013.V1.38

Chandralal, L., Rindfleish, J., \& Valenzuela, F. (2015). An application of travel blog narratives to explore memorable tourism experiences. Asia Pacific Journal of Tourism Research, 20(6), 680693.

\section{http://dx.doi.org/10.1080/10941665.2014.925944}

Chronis, A. (2012). Tourists as story-builders: Narrative construction at a heritage museum. Journal of Travel \& Tourism Marketing, 29(5), 444-459.

http://dx.doi.org/10.1080/10548408.2012.691395

Cimpoeş, P.O. (2013). History of research on the Land of Făgăraş. Studia UBB Geographia, 58(2), 157-168.

Dissart, J. C., \& Marcouiller, D. W. (2012). Rural tourism production and the experiencescape. Tourism Analysis, 17(6), 691-704.

http://dx.doi.org/10.3727/108354212X13531051127104

Diţoiu, M-C, \& Căruntu, A-L. "Sensory experiences regarding five-dimensional brand destination." Procedia-Social and Behavioral Sciences 109 (2014): 301-306.

http://dx.doi.org/10.1016/j.sbspro.2013.12.461

Edensor, T. (2007). Mundane mobilities, performances and spaces of tourism. Social \& Cultural Geography, 8(2), 199-215.

http://dx.doi.org/10.1080/14649360701360089

Elo, S., \& Kyngäs, H. (2008). The qualitative content analysis process.Journal of advanced nursing, 62(1), 107-115. 
http://dx.doi.org/10.1111/j.1365-2648.2007.04569.x

Figueiredo, E. ,\&Raschi ,A. (2012). Immersed in green? Reconfiguring the Italian countryside through rural tourism promotional materials. Advances in Culture, Tourism and Hospitality Research, 6, 17-44.

Franzoni, S. (2015). Measuring the sustainability performance of the tourism sector. Tourism Management Perspectives, 16, 22-27.

http://dx.doi.org/10.1016/j.tmp.2015.05.007

Funk, D. C., \& Bruun, T. J. (2007). The role of socio-psychological and culture education motives in marketing international sport tourism: a cross-cultural perspective. Tourism Management, 28(3), 806-819.

http://dx.doi.org/10.1016/j.tourman.2006.05.011

Gesser, G., Hornung-Prähauser, V., \& Strasser, A. (editors) ( 2014). Handbook for Creative Cultural Heritage Cooperation Projects. Salzburg: Creative Commons.

Greaves, N., \& Skinner, H. (2010). The importance of destination image analysis to UK rural tourism. Marketing Intelligence \& Planning, 28(4), 486-507.

http://dx.doi.org/10.1108/02634501011053586

Govers, R., Go, F. M., \& Kumar, K. (2007). Virtual destination image a new measurement approach. Annals of Tourism Research, 34(4), 977-997.

http://dx.doi.org/10.1016/j.annals.2007.06.001

Halfacree, K.. (2014). A critical response to the (non-) place of rural leisure users within the counter urban imagination. PASOS. Revista de Turismo y Patrimonio Cultural, 12(3), 515-523.

Haven-Tang, C., \& Sedgley, D. (2014). Partnership working in enhancing the destination brand of rural areas: A case study of Made in Monmouthshire, Wales, UK. Journal of Destination Marketing \& Management, 3(1), 59-67.

http://dx.doi.org/10.1016/j.jdmm.2013.12.001

Hu, T., Marchiori, E., Kalbaska, N., \& Cantoni, L. (2014). Online representation of Switzerland as a tourism destination: An exploratory research on a Chinese microblogging platform. Studies in Communication Sciences, 14(2), 136-143.

http://dx.doi.org/10.1016/j.scoms.2014.12.001

Ispas, A., Constantin, C., Candrea, A.N. (2015). An Examination of Visitors' Interest in Tourist Cards and Cultural Routes in the Case of a Romanian Destination. Transylvanian Review of Administrative Sciences, 46, 107-125.

Jiang, Y., Ramkissoon, H., \& Mavondo, F. (2015). Destination marketing and visitor experiences: The development of a conceptual framework. Journal of Hospitality Marketing \& Management, 123.

http://dx.doi.org/10.1080/19368623.2016.1087358

Kastenholz, E., Carneiro, M. J., \& Marques, C. (2012). Marketing the rural tourism experience. Strategic marketing in tourism services, 247-264.

Kavoura, A., Bitsani, E. (2013). E-branding of rural tourism in Carinthia, Austria. Tourism Review, 61, 3, 289-312.

Kim, J.H. (2014). The antecedents of memorable tourism experiences: The development of a scale to measure the destination attributes associated with memorable experiences. Tourism Management, 44, 34-45.

http://dx.doi.org/10.1016/j.tourman.2014.02.007

Kim, J.H., Ritchie, J.B.R., \& McCormick, B. (2012). Development of a Scale to Measure Memorable Tourism Experiences, Journal of Travel Research, 51(1), 12-25.

http://dx.doi.org/10.7903/cmr.13822

Kim, H., Stepchenkova, S. (2015). Effect of tourist photograps on attitudes towards destination: manifest and latent content. Tourism Management, 49, 29-41.

http://dx.doi.org/10.1016/j.tourman.2015.02.004 
Kuutma, K. (2011). Cultural heritage: an introduction to entanglements of knowledge, politics and property. Journal of Ethnology and Folkloristics, 3(2), 5-12.

Lindstrom, M. \& Kotler, P. (2005). Brand sense build powerful brands through touch, taste, smell, sight, and sound. New York, Free Press

Loureiro, S. M. C. (2014). The role of the rural tourism experience economy in place attachment and behavioral intentions. International Journal of Hospitality Management, 40, 1-9.

http://dx.doi.org/10.1016/j.ijhm.2014.02.010

Lugosi, P., \& Walls, A. R. (2013). Researching destination experiences: Themes, perspectives and challenges. Journal of Destination Marketing and Management, 2(2), 51-58.

http://dx.doi.org/10.1016/j.jdmm.2013.07.001

Lund, N.F. (2012). The Application of Hollywood storytelling formula to destination marketing, In Richards, V. (ed.) The Destination Branding \& Marketing IV Conference proceedings, Cardiff, Wales, 5-7 December 2012, Cardiff: Welsh Centre for Tourism Research, 199-209.

Marine-Roig, E., \& Clavé, S. A. (2016). A detailed method for destination image analysis using user-generated content. Information Technology \& Tourism, 15(4), 341-364.

http://dx.doi.org/10.1007/s40558-015-0040-1

McCabe, S., \& Foster, C. (2006). The role and function of narrative in tourist interaction. Journal of tourism and cultural change, 4(3), 194-215.

http://dx.doi.org/10.2167/jtcc071.0

McKee, R., \& Fryer, B. (2003). Storytelling that moves people. Harvard Business Review, 81(6), 51-55.

Mossberg, L. 2008. Extraordinary Experiences through Storytelling. Scandinavian Journal of Hospitality and Tourism, 8(3): $195-210$.

http://dx.doi.org/10.1080/15022250802532443

Nechita, F., Sandru, C., Candrea, A. N., \& Taranu, D. (2014). Advertising and Heritage Interpretation. Transilvania University Press.

Nechita, F., Sandru, C., Candrea, A. N., \&Coman, C. (2015). Valorizing intangible cultural heritage through experiential tourism: a Romanian case study. Paper presented at 5th International Conference ob Tourism Management and Tourism Related Issues, Kos, Greece, 8-9 October 2015

Oh, H., Fiore, A.M., \& Jeoung, M. (2007). Measuring Experience Economy Concepts: Tourism Applications. Journal of Travel Research, 46: 119-132.

http://dx.doi.org/10.1177/0047287507304039

Oliveira, E., \& Panyik, E. (2015). Content, context and co-creation Digital challenges in destination branding with references to Portugal as a tourist destination. Journal of Vacation Marketing, 21(1), 53-74.

http://dx.doi.org/10.1177/1356766714544235

Pan, S., Lee, J., Tsai, H. (2014). Travel photos: motivations, image dimensions, and affective qualities of places. Tourism Management, 40, 59-69.

http://dx.doi.org/10.1016/j.tourman.2013.05.007

Piccoli, G., Lui, T. W., \& Grün, B. (2017). The impact of IT-enabled customer service systems on service personalization, customer service perceptions, and hotel performance. Tourism Management, 59, 349-362.

http://dx.doi.org/10.1016/j.tourman.2016.08.015

Pine, B. J., \& Gilmore, J. H. (1998) Welcome to the experience economy. Harvard Business Review, 76, 97-105.

Pine, B. J., \& Gilmore, J. H. (1999). The experience economy: work is theatre \& every business a stage. Harvard Business Press.

Richards, G. (2010). Increasing the attractiveness of places through cultural resources. Tourism, Culture \& Communication, 10(1), 47-58. https://doi.org/10.3727/109830410X12629765735678 
Richards, G., \& Wilson, J. (2006). Developing creativity in tourist experiences: A solution to the serial reproduction of culture?. Tourism management, 27(6), 1209-1223.

http://dx.doi.org/10.1016/j.tourman.2005.06.002

Rieple, A., \& Pisano, P. (2015). Business Models in a New Digital Culture: The Open Long Tail Model. Symphonya, (2), 75.

http://dx.doi.org/10.4468/2015.2.06pisano.rieple

Ries, Al, and Laura Ries. "The 22 immutable laws of branding." Symphonya. Emerging Issues in Management 1 (2001): 30-34. http://dx.doi.org/10.4468/2001.1.04ries.ries

Ritchie, J.R.B. and Crouch, G. (2003) The Competitive Destination: A Sustainable Tourism Perspective. CABI Publishing: Cambridge, MA.

Royo-Vela,M.(2009). Rural-cultural excursion conceptualization: A local tourism marketing management model based on tourist destination image measurement. Tourism Management, 30(3), 419-428.

http://dx.doi.org/10.1016/j.tourman.2008.07.013

Sandru, C. (2009) Studii şi confesiuni despre Drăguşul contemporan. Cluj-Napoca: Editura Presa Universitară Clujeană.

Scârneci F. (2007). Îndrumar de cercetare calitativă în ştiinţele socio-umane. Braşov: Editura Universităţii Transilvania Braşov.

Servidio, R., \& Ruffolo, I. (2016). Exploring the relationship between emotions and memorable tourism experiences through narratives. Tourism Management Perspectives, 20, 151-160.

http://dx.doi.org/10/1016/jtmp.2016.07.010

Smith, W. L. (2005). Experiential tourism around the world and at home: definitions and standards. International Journal of Services and Standards,2(1), 1-14.

http://dx.doi.org/10.1504/IJSS.2006.008156

Sharpley, R., \& Sundaram, P. (2005). Tourism: a sacred journey? The case of Ashram tourism, India. International Journal of Tourism Research, 7(3): 161-171.

http://dx.doi.org/10.1002/jtr.522

Stepchenkova, S., Zhan, F. (2013) Visual destination images of Peru: comparative content analysis of DMO and user-generated content photography, Tourism Management, 36, 590-601.

http://dx.doi.org/10.1016/j.tourman.2012.08.006

Stepchenkova, S., Kim, H., Kirilenko, A. (2014). Cultural differences in pictorial destination images: Russia through the camera lenses of American and Korean tourists. Journal of Travel Research, 1-16.

http://dx.doi.org/10.1177/0047287514535849

Tung, V. and Ritchie, J.R.B. (2011) Exploring the essence of memorable tourism experiences. Annals of Tourism Research, 38(4), 1367-1386.

http://dx.doi.org/10.1016/j.annals.2011.03.009

UNESCO (2003). Convention for the Safeguarding of Intangible Cultural Heritage, http://www.unesco.org/new/en/media-services/in-focus-articles/2003-convention-for-thesafeguarding-of-intangible-cultural-heritage-gains-momentum/ (retrived: 24.04. 2015).

Urry, J. (2002). The Tourist Gaze (2nd ed.). London: Sage Publications.

Volo, S. (2009) Conceptualizing Experience: A Tourist Based Approach, Journal of Hospitality Marketing \& Management, 18:2-3, 111-126.

http://dx.doi.org/10.1080/19368620802590134

World Tourism Organization. 2012. Tourism and Intangible Cultural Heritage. Madrid: UNWTO.

Zhou, L. (2014) Online rural destination images: Tourism and rurality. Journal of Destination Marketing \& Management 3, 227-240.

http://dx.doi.org/10.1016/j.jdmm.2014.03.002 